\title{
Substance abuse and criminal behaviours among commercial vehicle drivers in Lagos state
}

\begin{abstract}
This study critically examines the relationships between substance abuse and criminal behaviours among the commercial motor drivers in Lagos State and relates it to national development. Relevant literatures were reviewed to lay solid explanatory foundation for the study. The study made use of social learning and personality theories in its theoretical framework. The study adopted survey research method. Surulere local government area was scientifically selected as the study location. Sample size of one hundred and sixtyfive (165) was purposively selected to sample the opinions of the respondents. The research work adopted mixed method to collect data. Self-administered questionnaire and in-depth interview (IDI) were the instruments used. The data gathered from the field were analysed using frequency distribution (uni-variate analysis) to assess and describe the study participants, while chi-square $\left(\chi^{2}\right)$ (bi-variate analysis) to test the relationship between the variables. Content analysis was also used to analyse the qualitative data generated from the field. The findings of the two hypotheses tested revealed that there is no significant relationships between abuse of alcohol by the commercial vehicle drivers and their involvement in road accidents which may result to loss of lives of many that should contribute meaningfully to the national development, but there is significant relationship between abuse of marijuana by the commercial vehicle drivers and their involvement in traffic offence. The study then recommends among others that Lagos State government must place strict ban on the sales of psychoactive substances in public places especially in the public motor parks.
\end{abstract}

Keywords: alcohol, commercial vehicle drivers, criminal behaviours, marijuana, substance abuse, paraga (alcohol herbal mixture)
Volume 8 Issue I - 2020

\author{
Olaniyi Damola Toyosi \\ Department of Sociology, University of Lagos, Nigeria
}

Correspondence: Olaniyi Damola Toyosi, M.Sc. Sociology, Department of Sociology, University of Lagos, Nigeria, Tel +234(0)7031035508, Email oyinoluwa2013@gmail.com

Received: December 19, 2019 | Published: January 30, 2020
Abbreviations: AI/AN, American Indian and Alaska native; BAC, blood alcohol concentration; CNS, central nervous system; NAFDAC, National agency for food and drugs administration and control; NURTW, National union of road transport workers; RTEAN, road transport employees association of Nigeria; WHO, world health organization

\section{Introduction}

Crimes and deviant behaviour bring about insecurity in any society and remain part of the major impediments to development in any nation. A society thrives when criminalities and social menace that could threaten its security are controlled. Nwanegbo et al., ${ }^{1}$ stress that security is evidently the pillar upon which every meaningful development could be achieved and sustained. Iwerimie Jaja et al., ${ }^{2}$ posits further that without law and order, there would be no stability and sustainable development in any society. Victims of crimes and social vices suffer the loss of lives and property which can retard socio-economic development in the country. Discussing further on the concept of national development, Tolu et al., ${ }^{3}$ submit that it is the ability of a country or countries to improve on social welfare of its people vis-a-vis provision of quality education, potable water, transportation, good roads, medical care etc. with the aim of achieving increase in real per capita income. Hence, this paper examines the implication of substance abuse and criminal behaviour among the commercial motor drivers on national development.
Without doubt, substance use has been of tremendous benefit to mankind. Nevertheless, it has also been acknowledged that its inappropriate use can cause incalculable harm not only to the users but to the larger society. Kaplan et al., ${ }^{4}$ posit hat inappropriate use of substance has a severe impact on the fabric of the society. They further state that use of substances is a global phenomenon with a lot of adverse effects on physical and mental health. The Nigerian society over the years has defined some substance as acceptable while others as not acceptable without reference to their effects on mental and physical wellbeing of the users. For instance, society considers the use of alcohol and nicotine as acceptable; hence those that take such substances do so freely in the public without fear of arrest or society stigma. In contemporary Nigeria society, if we look around in our immediate environment there seems to be high spread of drug use and abuse among many, mostly the young ones. Some of these substances may come in form of tablets, capsules, syrups or soluble, examples of such are codeine, tramadol, frenor, Alabuku. Some people sniff, swallow, inject or ingest them to get euphoria. In addition, substances such as eskey, crake, marijuana and many others mostly initiate in the users the ability to commit crimes. In support this, Adegboro ${ }^{5}$ asserts that use of illicit drugs has been linked with anti-social behaviours and criminality for many decades. Alcohol and marijuana were the top two on the list of substances abused. Adegboro further reported that violent behaviour like sexual assault and violent crimes were common among substance abusers. 
Similarly, Makanjuola et al., ${ }^{6}$ pointed out that the use of psychoactive substances, especially alcohol, was really common among long distance vehicle drivers in Nigeria. In a study carried out by Abiona et al., it was revealed that all the respondents (commercial vehicle drivers) engaged in the use of commonly available alcoholic beverages in various motor parks. The sale of marijuana, cannabis and the likes go along side with the alcoholic beverages in various motor parks in Lagos State. No fewer than 162 commercial bus drivers in just two motor parks at Oyingbo and Iyana-Ipaja have tested positive for cocaine and marijuana, while another 996 commercial bus drivers tested positive use to driving under the influence of strong alcohol. Oyebode stress further that the former governor of the state (Babatude Fashola) lamented that several commercial bus drivers in the state drive under the influence of strong alcohol.

Moving around Lagos metropolis these days, most public places including motor parks seems to have drug markets or vendors peddling series of substances. Places like Akala in Mushin, Oshodi and several other locations across the state have drug cartels. Someone somewhere sells psychoactive substances to people and those that take them know where to have easy access to them. To worsen the matter, our society appears to pay little or no attention to this social malaise. Some people are so much at home with the use of substance to the point that they take it to the extreme. Hence, the abuse of it becomes inevitable. And because they do not control it, it eventually controls them to act negatively.

It may surprise us that a frightening number of people engage in using or abusing drugs with the impression of being euphoric, selfconfident, and energetic especially among the young folks. Studies have shown that abuse of drugs invariably leads to problems such as suicide, drowning, disruption of schooling and family life, delinquency, drunk-driving and accident. And also, loss of productivity, loss of jobs, legal difficulties, violent or aggressive behaviour, disordered social relationship and avoidable deaths. ${ }^{6,9,10}$ Not only do alcohol intake and drug abuse contribute to the above mentioned problems; they also threaten the fundamental of the social fabrics of society such as values, beliefs and cultural systems, and can cause a wide range of mental illnesses which are not necessarily reversible. ${ }^{11}$

The problem of substance abuse is so endemic that it was estimated that there are about fifty million addicts in the world and three times as many alcohol, hemp and tranquilizer users. ${ }^{12}$ Due to its availability in our society, it is clear that the problem added to other social problems in which Nigeria's reputation has been greatly at stake. Supporting this fact Iwerimie-Jaja ${ }^{2}$ affirmed that crimes (e.g. drug trafficking/abuse and human trafficking etc.) have damaged Nigeria's international image.

The issue of substance abuse and crime is common. They happen at regular intervals. It was reported in a study conducted on the American Indian and Alaska native (AI/AN) communities by Wood ${ }^{13}$ that for many in, crime-especially violent crime-is synonymous with the use and abuse of alcohol and other drugs. Substance use is very common among Nigerians which of course include the public vehicle drivers across the country. According to Iwerimie-Jaja ${ }^{2}$ Nigerians are a substance/drug-using society. He further affirms that in the market are consciousness-altering substance such as marijuana, heroin and cocaine. The public safety in the excessive use of these drugs is that it can influence their users to commit crime and delinquency. ${ }^{2}$

Moreover, it is a common thing to find people selling several kinds of substance ranging from alcohol, India hemp and the likes in public places particularly at motor parks across the country. This has created avenues for the commercial vehicle drivers and their assistants to patronize substance vendors at the parks and feel high at any time. With this observation, substance abuse is a common phenomenon among the commercial vehicle drivers in Nigeria especially Lagos State.

Also, it has been noted that the society contributes vastly to the rate of substance abuse among this set of group in the society. The level of poverty and high rate of unemployment in the country made several people to engage in unregulated business to make ends meet. This is why the sales of Central Nervous System (CNS) active agents like alcohol herbal mixture also known as "paraga", Indian hemp and the rest are commonly found in all the motor parks in the state. Oluwadiya et al., ${ }^{14}$ aver that "paraga", an alcoholic herbal preparation that comes in different varieties had been shown to be commonly available to commercial vehicle drivers in southern Nigeria.

Oyeniyi argues that "there have been numerous anecdotes (stories) and newspapers reports that paraga makers sometimes include psychoactive herbs such as cannabis and cocaine as well as alcohol in paraga to add some 'kick' to their product. Going by the argument of Oyeniyi, it is clear that several criminal/deviant behaviours such as, rape, street fight, dispossession of commuters valuables items, bullying, serious abuse and beating of commuters at slightest disagreements which are commonly found among the commercial vehicle drivers may directly or indirectly link to their use of psychoactive substance, notably their intake of paraga.

There are numerous cases of the commercial driver violation of traffic rules and making the roads not to be comfortable for other road users. Likewise, the cases of the commercial vehicle drivers' connivance with the ritualists and the armed robbers on the highways at nights and in the day is a problem. The involvement of some of these drivers in the abovementioned problems may be directly or indirectly connected to the intake of substance. Several studies have shown reasons behind substance abuse, which if critically look into could trigger unacceptable behaviours among the users. Okuh, ${ }^{15}$ Oduaran ${ }^{16}$ and Johnson ${ }^{17}$ in Fareo ${ }^{18}$ maintain that there are plethoras of purposes for which drugs are used. The list includes curiosity, boldness, friendsdo-it, enjoyment of social gathering, sound-sleep, sexual-prowess, and so on. It is in the light of the above stated problems and many others that the study explore the nexus between substance abuse and criminal behaviour among commercial vehicle drives in Lagos State. To achieve the above, the study specifically seeks to:

(1) Determine the relationship between abuse of alcohol and commercial vehicle drivers' involvement in road accidents.

(2) Investigate the relationship between abuse of marijuana and commercial vehicle drivers' involvement in traffic offence.

\section{Research hypotheses}

In order to achieve the general objective of the study, the following hypotheses were formulated.

1) There is a relationship between abuse of marijuana and commercial vehicle drivers' involvement in road accident.

2) There is a relationship between abuse of alcohol and commercial vehicle drivers' involvement in traffic offence. 


\section{Conceptual discussion}

\section{Substance abuse}

The term "substance abuse" connotes excessive and persistent self-administration of a drug without regard to the medically or culturally accepted patterns. It could also be viewed as the use of a drug to the extent that it interferes with the health and social function of an individual. ${ }^{19}$ World Book Encyclopaedia ${ }^{20}$ defined substance abuse as the non-medical use of a drug that interferes with a healthy and productive life. In his own definition, Manbe ${ }^{21}$ defined it as the excessive, maladaptive or addictive use of drugs for non-medical purpose.

Substance abuse, according to Ajayi et al., ${ }^{22}$ is the wrong use or inappropriate use of chemical substance that are capable of changing functions of cells in the body. Bayer, as cited in Egbochuku et al., ${ }^{23} \mathrm{saw}$ stimulants, which are substance that cause an increase in the activity of an organ in the body, as chemicals that incite certain activities of the central nervous system. Ajayi et al., ${ }^{24}$ also saw substance abuse as over-dependence and misuse of one particular drug with or without a prior medical diagnosis from qualified health practitioners. They further identified dangerous drugs like cocaine, Indian hemp (marijuana), morphine, heroin, tobacco, ephedrine, valium5 and Chinese capsules as few among the drugs commonly abused.

Substance abuse according to Laver ${ }^{25}$ simply means the improper use of substance to the degree that the consequences are defined as detrimental to the user and or the society. The $\mathrm{WHO}^{26,27}$ also defined it as a "state" of periodic or chronic intoxication, detrimental to the individual and to the society, produced by the repeated consumption of a drug (natural or synthetic). Its patterns include all aspect of drug or substance usage ranging from how much, how often and what sort of substance, where, who, with what circumstances and so on. Traditionally, the term "substance" abuse refers to the use of any drug prohibited by law, regardless of whether it was actually harmful or not. This meant that any use of marijuana for example, even if it occurred only once in a while, would constitute abuse, while the same level of alcohol consumption would not. The analysis of contemporary social problem has consistently proved more and more controversial because of the variables involved. The incidence of substance abuse is of utmost concern to the abuser himself, his family, the government and the entire society in which he lives. ${ }^{28}$

\section{Criminal act/behavior}

There are two ways to the definition of criminal behaviour. It can be defined from both legal and social perspectives. From legal perspective criminal act is said to be acts or omissions forbidden by law that can be punished by imprisonment and/or fine. Murder, robbery, burglary, rape, drunken driving, domestic violence and many others are common examples of criminalities. According to the Oxford English Dictionary ${ }^{29}$ crime is simply defined as "an action or omission which constitutes an offence and is punishable by law", while the Oxford Dictionary of Sociology $y^{30}$ put it as "an offence which goes beyond the personal and into the public sphere, breaking prohibitory rules or laws, to which legitimate punishments or sanctions are attached, and which requires the intervention of a public authority. ${ }^{30}$ Marshall ${ }^{31}$ as that crime can be simply defined as an offence which goes beyond the personal and into the public sphere, breaking prohibitory rules or laws, to which legitimate punishment or sanctions are attached, and requires the intervention of a public authority i.e. the State or a local body. In the same vein, Henslin defines crime as the violation of rules that have been written into law. In the light of the above definitions, crime is, therefore, a social problem in the society due to the negative consequences on its well-being.

\section{The use of marijuana}

Hilgard in a study reveals that marijuana is derived from "hemp". Makinde alluded that, in Nigeria, this drug is known by various names such as "ganga", "igbo", "weewee", "winwin", "india hemp", "cannabis", "shit", "kpakpa", "pot", "grass", and "weed" et cetera. The mode of consumption of this drug in Nigeria is by smoking the prepared leaves and flowering seeds. ${ }^{32}$ On the use of the drug, the above named author further explicate that there are no known medical uses of the drug in Nigeria. They added that the effect, which appear to depend on the potency of the preparation and the amount consumed, are both psychological and behavioural. Other study on the effects of marijuana claimed that the dried leaves of the plant have the effects of driving smokers completely insane.

One major thing about the drug is that the abusers and/or addict loses sense of moral responsibility. While under the influence of the marijuana they are immune to pain and could be severely injured without having any realization of their condition. While in the condition, they become raving maniacs and liable to or indulge in any form of violence to other persons using the most savage methods of cruelty without any sense of moral responsibility. ${ }^{33}$

\section{The consumption of alcohol}

According to $\mathrm{WHO}^{27}$ in Okpataku ${ }^{34}$ the use of alcohol and other substances is increasing in most parts of the world and there is a growing concern about this trend and its consequences. Alcoholic drink is any beverages that contain ethyl alcohol in intoxicating quality. The amount of alcohol may be as little as $2 \%$ as in some beers or wines, or it may be as much as $68 \%$ as in "ogogoro". ${ }^{33}$ Smith and Gips, Maddox pointed out that alcohol is a depressant, not a stimulant. Many users claim that alcohol exits rather than depresses them. However, the feeling of stimulation results from the lessening of inhibition.

Alcohol abuse has not yet received sufficient public attention though it is on the increase. Pela et al., ${ }^{32}$ reported that the astronomical increase in the number of breweries in Nigeria has brought, on the one hand, considerable economic reward to Government and investors, while on the other hand, it is beginning to cause concern over alcohol related problem and their attendant economic, social and medical adverse effects upon the individual, family and community. According to Owuamanan, among the consequences of drinking alcohol reported are: drunkenness, physiological damage, traffic and other accidents.

\section{Theoretical underpinning}

Several theories of substance abuse indicate that some people depend on certain substances for their survival or performance due to a number of factors. The major emphasis of the theories is that people have their individual reasons for depending on one type of substance or the other. In order to enhance the explanatory power of this paper, social learning theory and personality theories as the theoretical underpinning.

\section{Social learning theory}

The theory is an attempt made by Albert Bandura in 1971 to 
describe learning as a cognitive process that takes place in a social context and can occur purely through observation or direct instruction, even in the absence of motor reproduction or direct reinforcement. ${ }^{35-37}$ In addition to the observation of behaviour, learning also occurs through the observation of rewards and punishments, a process known as vicarious reinforcement. The theory expands on the traditional behavioural theories, in which behaviour is governed solely by reinforcements, by placing emphasis on the important roles of various internal processes in the learning individual. The theory integrated behavioural and cognitive theories of learning in order to provide a comprehensive model that could account for the wide range of learning experiences that occur in the real world. Observational learning could not occur unless cognitive processes were at work. Take for instance, children observe the people (Model) around them behaving in various ways. These models could be parents within the family, characters on TV, friends within their peer group, teachers at school et cetera. These provide examples of behaviour to observe and imitate. These models could be actual persons demonstrating the desired behaviour, individual describing the desired behaviour through verbal instruction or modelling through media platforms.

Therefore, learning theory of drug abuse maintains that dependence or abuse of drugs occurs as a result of learning. The learning could be by means of conditioning, instrumental learning or social learning. The theory further maintains that usage or dependence on substance occurs as a result of either conditional learning or social learning. This is prevalent among the youths; several reports have revealed that substance abuse is as a result of peer influence. The most prominent antecedent of substance abuse, however, is simply the exposure to substance being used. Among the factors associated with substance abuse are the prevalence of substance use in one's social environment and the general availability of drugs in one's surroundings, as well as social norms favouring drug related behaviours. ${ }^{38}$

The social learning aspect of drug abuse is also related to parental modelling of drug related behaviours. Several theories were in support of the fact that parental drug use predicts initiation of drug use by children. This, therefore, shows that parents also play a key role in influencing their children to do what they do. Despite all the drug abuse antecedents, the strongest predictor of drug use remains substance abuse by peers.

\section{Personality theories}

Lamiel $^{39}$ noted that defining personality is itself a matter of personality, since psychologists have not yet settled on any definition of personality that is substantive, precise and generally agreed upon. However, Kleinmuntz (1982) defines personality as the organization of characteristics that define an individual and determine that person's pattern of interaction with the environment. Irrespective of definition that may be given to personality one major question is germane and that is "how does personality develop?" Or "Is an individual's personality stable over time or can it change in response to certain situations or stimuli?" The psychologists talk about personality in deferent ways. The study will consider among others the psychoanalytic personality theory of Sigmund fraud.

Sigmund Freud ${ }^{40}$ believed that most behaviour are caused by thoughts, ideas, and wishes that are in a person's brain but are not easily accessible by the conscious part of the mind. In other words, your brain knows things that your mind does not. He emphasized that "We are not even the masters of our own minds, but are driven by many powerful unconscious processes (wishes, fears, beliefs, conflicts, emotions, memories) of which we are totally unaware". ${ }^{40}$

This reservoir of conceptions of which we are unaware is called the unconscious. Psychoanalytic theory proposes that personality characteristics are mostly a reflection of the contents of the unconscious part of the mind. ${ }^{39}$ Fraud conceived of human being as having three interrelated parts: the id, the ego and the superego.

This paper focuses on ego to further discuss the relationship between this theory and substance abuse and criminal behaviour among the commercial vehicle drivers. The ego operates on the reality principle, that is, it tries to satisfy the needs of the id in socially acceptable ways. It develops from our experiences in our environment as we come to understand that we are separate or distinct from other people and the things around us. It is best described as the aspect of the personality that is rational, oriented toward solving problems, and able to delay gratification. As the ego grows, so does the individual's ability feeling to deal with reality. ${ }^{41}$

The Freudian psychoanalytic perspective posits that the major cause of delinquency and criminal behaviour is the malfunctioning of either ego or superego. Curran et al., ${ }^{41}$ argued that parental neglect may result in an underdeveloped superego. A number of psychologists have reported a lack of love and care in the backgrounds of delinquent children and criminal adults. Such individuals did not adequately internalize societal norms. Their non-conformity is an expression of unregulated id impulses. ${ }^{31}$

Delinquency and crime may also be a result of an immature or underdeveloped ego. A lack of physical affection in infancy, indulgent parents who give in to their child's every whim and caprices, or conversely, parents who persistently frustrate their child, are apt to cause the child to become fixated in a particular psychosexual stage of development. ${ }^{31}$

The main emphases of personality theories are that there are certain traits or characteristics in the individuals that abuse drugs. Such personality characteristics, according to Eze et al.,42 are inability to delay gratification, low tolerance for frustration, poor impulse control, high emotional dependence on other people, poor coping ability and low self-esteem. Individuals with these personality characteristics find it difficult to abstain from drug/substance abuse.

\section{Methods}

The quality of any research work depends to a large extent on the method of data collection used. Hence, the research technique that was used for this study is described below. A survey research method was adopted to enable the researcher and the subject of study to interact. The study location is Surulere Local Government Area of Lagos state with a specific focus on the commercial vehicle drivers operating at the various motor parks within the local government. The study population age involved drivers within the official driving age of 18 to 60 years.

The study population comprised of the all the commercial vehicle drivers in Surulere Local Government Area of Lagos State. There are five major approved motor garages in the local government area, that is; Aguda, Lawanson, Masha-Kilo, Ojuelegba, and Yaba (by Tejuosho Market). Out of the above mentioned, a simple random sampling method was utilised to select three (3) motor parks, which are; Aguda, Ojuelegba, and Yaba (by Tejuosho Market). The study 
sample size was put at one hundred and sixty-five (165). Purposive sampling method was used to selecte respondent for the above sample size. This was made on the basis of the available information and researcher's knowledge of the study population. Fifty-five (55) respondents were selected from each of the three selected motor parks. The study adopted mixed method in collecting data. That is, questionnaire and (In-depth Interview) IDI. The commercial vehicle drivers operating at the selected motor parks were the respondents for the questionnaire, while respondents for the IDI were drawn from the people that operate in and around the motor parks. These were the law enforcement officers, senior officials of the motor drivers' union (NURTW and RTEAN) and head of business operators there. Twelve (12) respondents were selected for the IDI, four (4) from each of the three selected parks that were randomly selected. ${ }^{43-47}$

One hundred and sixty-five (165) questionnaires were administered to elicit information from commercial vehicle drivers at the parks. One hundred and fifty-nine (159) were retrieved and processed. The questionnaire was divided into sections; the sociodemographic information of the respondents and relevant question that focused on the study's specific objectives. A validity and reliability test was carried out on the instruments. Each copy of the instruments were given to a research supervisor for corrections, comments and suggestions in order to improve on its content and construct. A pre-test study was conducted at motor parks at Ikorodu Local Government Area of Lagos State. Data gathered from the field were analysed using frequency distribution (univariate analysis) and chi-square $\left(\chi^{2}\right)$ (bivariate analysis) to test the relationship between the variables. Content analysis was also used to analyse the qualitative data generated from the field.

\section{Testing of hypotheses}

The Table 1 above indicates the sex of the respondents, that $98.7 \%$ of the respondents were male, while $1.3 \%$ were female. Their age as at last birthday shows that $3.8 \%$ of the respondents were between 15 19 years of age, $12.6 \%$ were between ages $20-24$ years, $23.3 \%$ were between ages $25-29$ years, $13.8 \%$ were between ages $30-34$ years, $22.0 \%$ were between ages $35-39$ years, $4.4 \%$ were between ages 40 44 years, $10.1 \%$ were between ages $45-49$ years, $3.1 \%$ were between ages $50-54$ years, while $6.9 \%$ were from 55 years and above. The Minimum age of the respondents is 18 years, Maximum age is 60 years, Average (Mean) age is 34 years. Also, The data distribution of respondents by religion in the same table shows that $53.5 \%$ of the respondents were Christians, $40.3 \%$ were Muslims, $4.4 \%$ practices traditional religion, while $1.9 \%$ did not practice any religion. Their marital status indicates that $50.3 \%$ of the respondents were singles, $13.2 \%$ were cohabiting, $27.7 \%$ were married, $2.5 \%$ were divorced, $3.8 \%$ were separated, while $2.5 \%$ were widowed. ${ }^{48-50}$

Likewise, level of education attained reveals that $5.0 \%$ of the respondents had no formal educational background, $24.5 \%$ had primary education, and $40.9 \%$ had secondary education, while $5.0 \%$ had post-secondary education. Lastly, the distribution of respondents by employment status shows that $45.3 \%$ of the respondents were self-employed, $8.2 \%$ were employed, $44.7 \%$ were employee, while $1.9 \%$ falls under other categories. That is, the self-employed were the owners of the vehicles that they use for transport business, the employers were those who employed drivers to use their vehicles for the business, the employees were those employed to drive the vehicles, while others were the short-time drivers. These were those that were lent vehicles by their colleagues to use to make some money just for a short time in a day.
Table I Socio-demographic characteristics of the respondents

\begin{tabular}{|c|c|c|}
\hline Responses & Frequency & Percentage \\
\hline \multicolumn{3}{|l|}{ Sex } \\
\hline Male & 157 & 98.7 \\
\hline Female & 2 & 1.3 \\
\hline \multicolumn{3}{|l|}{ Religion } \\
\hline Christianity & 85 & 53.5 \\
\hline Islam & 64 & 40.3 \\
\hline Traditional & 7 & 4.4 \\
\hline None & 3 & 1.9 \\
\hline \multicolumn{3}{|l|}{ Age Group } \\
\hline $15-19$ & 6 & 3.8 \\
\hline $20-24$ & 20 & 12.6 \\
\hline $25-29$ & 37 & 23.3 \\
\hline $30-34$ & 22 & 13.8 \\
\hline $35-39$ & 35 & 22 \\
\hline $40-44$ & 7 & 4.4 \\
\hline $45-49$ & 16 & 10.1 \\
\hline $50-54$ & 5 & 3.1 \\
\hline 55 years and above & II & 6.9 \\
\hline \multicolumn{3}{|c|}{ Mean age $=34.45$, Min. $=18$, Max. $=60$} \\
\hline \multicolumn{3}{|l|}{ Marital Status } \\
\hline Single & 80 & 50.3 \\
\hline Cohabiting & 21 & 13.2 \\
\hline Married & 44 & 27.7 \\
\hline Divorced & 4 & 2.5 \\
\hline Separated & 6 & 3.8 \\
\hline Widowed & 4 & 2.5 \\
\hline \multicolumn{3}{|l|}{ Level of Education } \\
\hline None & 8 & 5 \\
\hline Primary & 39 & 24.5 \\
\hline Secondary & 65 & 40.9 \\
\hline Post-secondary & 39 & 24.5 \\
\hline Graduate & 8 & 5 \\
\hline \multicolumn{3}{|l|}{ Employment Status } \\
\hline Self-employed & 72 & 45.3 \\
\hline Employer & 13 & 8.2 \\
\hline Employee & 71 & 44.7 \\
\hline Others & 3 & 1.9 \\
\hline Total & 159 & 100 \\
\hline
\end{tabular}

Source: Field Survey 


\section{Decision region}

The decision region is based on the rules that if the P-value (i.e. asymptomatic value) is less than 0.05 , there is a significant relationship. But if the P-value is higher than 0.05 , then there is no relationship.

Hypothesis one: There is a relationship between abuse of alcohol and commercial vehicle drivers' involvement in road accidents (Table 2).

Table 2 Abuse of alcohol and commercial vehicle drivers' involvement in road accident

\begin{tabular}{|c|c|c|c|}
\hline \multirow[t]{2}{*}{$\begin{array}{l}\text { Do you take } \\
\text { alcohol? }\end{array}$} & \multicolumn{2}{|c|}{$\begin{array}{l}\text { Have you ever involve in hit } \\
\text { and run }\end{array}$} & \multirow[t]{2}{*}{ Total } \\
\hline & Yes & No & \\
\hline Yes & $10(6.3 \%)$ & $98(61.6 \%)$ & $\begin{array}{l}108 \\
(67.9 \%)\end{array}$ \\
\hline No & $10(6.3 \%)$ & $4 \mathrm{I}(25.8 \%)$ & $51(32.1 \%)$ \\
\hline Total & $\begin{array}{l}20 \\
(12.6 \%)\end{array}$ & $139(87.4 \%)$ & $\begin{array}{l}159 \\
(100.0 \%)\end{array}$ \\
\hline \multicolumn{4}{|c|}{$\chi 2=3.37, d f=1$, sig $(p$-value $)=0.066$} \\
\hline
\end{tabular}

Source: Field Survey, 2016

The Table above reveals that commercial vehicle drivers' abuse of alcohol will determine their involvement in road accidents. Which may have resulted into what is popularly known as hit and run. This decision was taken based on chi-square analysis where the calculated value $\left(\chi^{2}\right)$ is 3.37 , the degree of freedom (df) is 1 and the significance (p-value) is 0.066 which is slightly higher than the level of significance at 0.05 . This implies that the hypothesis is rejected and we conclude that there is no significant relationship between abuse of alcohol by the commercial vehicle drivers and their involved in road accidents which may have resulted into hit-and-run.

The table analysis shows that out of the total respondents $(67.9 \%)$ of those who take the substance, the minority $(6.3 \%)$ involve in hitand-run, while the majority $61.6 \%$ do not. Out of the total respondents $(32.1 \%)$ of those who do not take substance, the minority $6.3 \%$ involve in hit-and-run, while the majority $(25.8 \%)$ do. Hence, percentage of those who take the substance and involve in hit-and-run $(6.3 \%)$ is lower than those who do not but involve in it $(61.6 \%)$. So, those that involve in hit-and-run through alcohol abused are in the minority. The implication of this is that there is negative relationship between alcohol abuse and the commercial vehicle drivers' involvement in road accidents. ${ }^{51-52}$

Hypothesis two: There is a relationship between abuse of marijuana and commercial vehicle drivers' involvement in traffic offence (Table $3)$.

Table 3 Abuse of marijuana and commercial vehicle drivers' involvement in traffic offence

\begin{tabular}{llll}
\hline $\begin{array}{l}\text { How often do you } \\
\text { take marijuana? }\end{array}$ & \multicolumn{2}{l}{$\begin{array}{l}\text { Do you commit traffic } \\
\text { offence? }\end{array}$} & Total \\
\hline & Yes & No & \\
\hline Very often & $8(5.0 \%)$ & $6(3.8 \%)$ & $14(8.8 \%)$ \\
Often & $21(13.2 \%)$ & $6(3.8 \%)$ & $27(17.0 \%$ \\
Not often & $63(39.6 \%)$ & $19(11.9 \%)$ & $82(51.5 \%)$ \\
Not at all & $16(10.1 \%)$ & $20(12.6 \%)$ & $36(22.7 \%)$ \\
Total & $108(67.9 \%)$ & $51(32.1 \%)$ & $159(100.0 \%)$ \\
\hline$\chi 2=14.27 \mathrm{df}=3$, sig $(\mathrm{p}$-value $)=0.03$. & & \\
\hline
\end{tabular}

Source: Field Survey, 2016
The table above reveals that intake of marijuana among commercial vehicle drivers determine their involvement in traffic offence. This decision was taken based on chi-square analysis where the calculated value $\left(\chi^{2}\right)$ is 14.72 , the degree of freedom (df) is 3 and the significance (p-value) is 0.03 which is lesser than the level of significance at 0.05 . This implies that the hypothesis is accepted and we conclude that there is significant relationship between intake of marijuana by the commercial vehicle drivers and their involvement in traffic offence.

The table analysis further shows that out of the total percentage of respondents $(57.8 \%)$ commit traffic offence, the majority $(39.6 \%)$ take marijuana not often and the remaining minority of $5.0 \%$, and $13.2 \%$, respectively either take it very often or often, while $10.1 \%$ do not take marijuana at all but still commit traffic offence. Out of the respondents $(19.5 \%)$ who do not commit traffic offence, the majority $(11.9 \%)$ take marijuana not often, and the remaining $3.8 \%$ and $3.8 \%$ respectively either take it very often or often, while $12.6 \%$ do not take marijuana at all and do not commit the offence. Therefore, percentage of those who take marijuana and commit traffic offence (57.8\%) is higher than those who do not take marijuana but commit the crime $19.5 \%$. The implication of this is that there is positive relationship between marijuana intake and commercial drivers' involvement in traffic offence. So, substance abuse can indeed determines how commercial drivers commit crimes.

\section{Discussion of findings}

The result of the findings in hypothesis one revealed that there was no significant relationship between abuse of alcohol by the commercial vehicle drivers and their involvement in vehicle accidents. The table analysis shows that out of the total respondents $(67.9 \%)$ of those who take the substance, the minority $(6.3 \%)$ involve in hit-and-run, while the majority $61.6 \%$ do not. Out of the total respondents $(32.1 \%)$ of those who do not take substance, the minority $6.3 \%$ involve in hitand-run, while the majority (25.8\%) do. Hence, percentage of those who take the substance and involve in hit-and-run $(6.3 \%)$ is lower than those who do not but involve in it $(61.6 \%)$. So, those that involve in hitand-run through alcohol abused are in the minority. The implication of this is that there is negative relationship between alcohol abuse and the commercial vehicle drivers' involvement in road accidents. However, the findings here does not agree with the argument of the British Medical Association (1998) as cited in Makanjuola et al., ${ }^{6}$ that in motor accidents, there is a 2 -fold risk of having an accident if the driver has a blood alcohol concentration (BAC) of $80 \mathrm{mg} \%$. With a BAC of $100 \mathrm{mg} \%$, the risk increases to 7-fold, with a BAC of $150 \mathrm{mg} \%$, there is a 10 -fold increase while a BAC $200 \mathrm{mg} \%$ causes a 20 -fold increase. Furthermore, in another perspective, $\mathrm{WHO}^{27}$ in Adekoya et al., ${ }^{11}$ reported that road accident is traceable most times to the negligence of drivers and it constitutes a major cause of morbidity, mortality, disability and socio-economic loss. Hence, the following statements show that drivers' involvement in road accident may be because of their alcohol intake or their negligence while driving.

Furthermore, the findings from the qualitative data of the study revealed several other factors responsible for vehicle accident apart from substance use as bad roads, poor driving skills, use of bad/ or expired tyres, poor driving skills, failed break and general poor condition of the vehicle; also, deliberate attempt to flout traffic rules, answering of phone calls while driving and many more. In a response from a 40 year old female commuter at Ojuelegba Motor Park that; "Yes, drunk-driving along side with high speed often responsible for hit-and-run cases on our roads. If the speed of a driver is not too much, the substance in his body system will not have much control on the way he drives and he can easily avoid any unforeseen incidences that 
could cause accidents on the way. However, negligence of the driver and the victim of such accident cannot be ruled out. Deliberate attempt to flout traffic laws such as answering phone calls while driving is also part of it. There are other associating factors contributing to hitand-run or road accidents in our country, these are; bad roads, poor driving skills, bad condition of vehicle tyres or drivers use of expired tyres that have expired, break failure and general poor condition of the vehicle."

Also, in Hypothesis two it was revealed that there was significant relationship between intake of marijuana by the commercial vehicle drivers and their involvement in traffic offence. The table analysis further shows that out of the total percentage of respondents $(57.8 \%)$ commit traffic offence, the majority (39.6\%) take marijuana not often and the remaining minority of $5.0 \%$, and $13.2 \%$, respectively either take it very often or often, while $10.1 \%$ do not take marijuana at all but still commit traffic offence. Out of the respondents (19.5\%) who do not commit traffic offence, the majority (11.9\%) take marijuana not often, and the remaining $3.8 \%$ and $3.8 \%$ respectively either take it very often or often, while $12.6 \%$ do not take marijuana at all and do not commit the offence. Therefore, percentage of those who take marijuana and commit traffic offence (57.8\%) is higher than those who do not take marijuana but commit the crime $19.5 \%$. The implication of this is that there is positive relationship between marijuana intake and commercial drivers' involvement in traffic offence. So, substance abuse can indeed determines how commercial drivers commit crimes.

Adegboro $^{5}$ argued in support of the finding that alcohol and marijuana were the top two on the list of substance abused. He further reported that bad behaviours like sexual assaults and other offences or crimes are common among substance abusers. Furthermore, findings from the in-depth interview agreed with the result of the quantitative study as discussed above. Several respondent from the qualitative study said the drivers under the influence of substance like alcohol and marijuana do commit criminal offence like traffic offence, fighting, extortion (refusal to drop commuter at the right bus-stop after collection of transport fare), rape and sexual molestation, connivance with the robber to rob their vehicles at the expense of the commuters. Specifically, a Police officer whose station is around Ojuelegba Garage stated that: "We (policemen) use to see them whenever they commit the crimes and that is why we arrest them. They always conspire with armed robbers in using their vehicles to rob, and they also involve in traffic offence. From several of them [the commercial vehicle drivers] we either perceive the smell of alcohol in them or found prohibited substance like igbo [local name for "marijuana"] in their vehicle or pockets when we search them especially when they are arrested for traffic violations or other offences"

\section{Conclusion}

The result of the findings in this study revealed that substance use cannot be totally separated from criminal and anti-social behaviours that are found among commercial vehicle drivers in Lagos State particularly traffic violations and road accidents. Although the result of one of the hypotheses tested does not completely agree with the fact that intake of substance like alcohol could directly link to involvement of drivers in vehicle accidents. However, the situation surrounding substance abuse among the commercial vehicle drivers in the country is on the rise, mainly the commercial nerve centre like Lagos state. This has resulted into several social vices. Fekjaer in a study, enumerated some of the social problems associated with substance use as accidents like motor vehicle crashes and trauma resulting in disability, spousal abuse, fire and burns, poverty, under nutrition and malnutrition, unemployment, family divorce, social conflicts, social maladjustment, reduced productivity, criminal behaviours and decreased sexual arousal in both sexes.

Crimes and drug abuse are dangerous factors that are capable of producing devastating problems for the abusers and the society at large, especially when left uncontrolled. The study helps to further understand other connecting social factors that predispose drivers to abuse substance and commit crimes. Among which are: peer influence, availability of the substance, source of awareness and many others. The social learning theory of substance abuse by Bandura maintains that dependence on substance occurs as a result of learning. This leaning could be through models like parents, characters on TV, friends within a peer group, to mention but a few. These provide examples of behaviour to observe and imitate. These models could be actual persons demonstrating the desired behaviour, individual describing the desired behaviour through verbal instruction or modeling through media platforms. While Sutherland concludes that all criminality is learned in a process of social interaction. These theories reveal the nexus between substance abuse or use and also criminal activities by those who perpetrate them in the society. That is, there is tendency that those who engage in substance intake and also in crime might have some sort of model in which they imitate to engage in such acts.

Conclusively, in whatever ways we look at it, the general public is the one at the receiving end of the menace perpetrated by the commercial vehicle drivers. The frequency of substance intake and criminality among the drivers will continue unabated as long as the stakeholders fail to take the bull by the horns and find lasting solution to the menace. Thus, combating criminality and offences that are associated with substance abuse without restructuring the entire operations of these commercial vehicle drivers within the state may amount to efforts in futility.

\section{Recommendations}

Substance or drug abuse is generally perceived as harmful because of its destructive manifestations especially to those that abuse it and also the possibility that it helping to destroy lives that are suppose to contribute meaningfully to the development of the nation. As an ameliorative measure towards curbing the recurrent and continuous use of substance by the commercial vehicle drivers in Lagos state, the following recommendations are hereby suggested:

1. Lagos State government must place a strict ban on the sales of all forms of psychoactive substances that are ingested or injected by the drivers in the motor parks within the state. It is imperative for the state government to act swiftly in this regard so as to safeguard valuable lives that may get lost or maimed on the roads through road accidents. Other studies previously done by other authors revealed that the use of substances is a common thing among the commercial vehicle drivers in the state. This is not only limited to those that are operating within the state, but also inter-states vehicle operators which includes articulated vehicles.

2. The study also suggests that Lagos state government must create a sustainable method of checking drunk-driving on our roads or the intake of psychoactive substances by drivers. So as to forestall violation of traffic rules and also to safeguard lives of the people that are in contact with the roads in the state in one way or the other. 
3. The study shows that psychoactive substances can be commonly accessed by the drivers at the motor parks, therefore, sales and distribution of it at the motor parks in Lagos state must be forbidden. And state government must be proactive in dealing decisively with substance vendors at the parks or its vicinities.

\section{Acknowledgments}

This paper is an excerpt from the dissertation of my Master of Science (M.Sc.) Degree in Sociology. My utmost gratitude goes to the Almighty God the source of all that I am and all that I will ever be for the steady support He gave me to complete this study successfully. I wish to sincerely acknowledge my M.Sc. Degree supervisor, Prof. F.A.D. Oyekanmi, (whom both students and majority of the staff refers to as Mama in the Department), for the motherly guide, academic mentoring, encouragement and offering of consistent, constructive comments and direction for this research work. I found it a great and an unequal privilege to have been among the students under her supervision probably one of the last set of students to she supervised before her retirement from the University of Lagos [Unilag]. Likewise, I will like to appreciate Dr. Michael Kunnuji who also supervised my work when Mama was on her last annual leave in Unilag. I will always remember the brotherly love and support received from Dr. David Akeju of the Department of Sociology, Unilag for finding times to attend to me every time I beckoned on him for assistance throughout my study at the University of Lagos. I wish to say thank you to Dr. Niyi Adegoke of National Open University of Nigeria (NOUN) for his support.

This academic achievement will not have been better achieved without academic impartations I received from the crops of fine academics in the Department of Sociology, University of Lagos also known as Unilag. I want to say a big thank you to my lecturers, at least those that i passed through their tutelage during the M.Sc. programme, Prof. Adebayo Ninalowo, Prof Omololu Soyombo, Prof. Ndukaeze Nwabueze, Prof. Bammeke (Now the Dean faculty of Social Sciences), Associate Prof. Lakan Oyefara, Dr. Franka Attoh, Dr. Michael Kunnuji. I also appreciate several other lecturers that I may not be able to mention here due to space.

I would like to give my deepest thanks to the entire family member of Olaniyi especially my mother Mrs. Deborah K. Olaniyi who is now the head of the home after the demise of her beloved husband. I say thank you ma for always being there for me in all and at all times and for always wanting us all to be the best in life. To Revd. Segun Adegbola I say thank you sir.

Finally, to all my friends and colleagues in the Department of Sociology 2014-2015 Masters set, Olatunji Olayemi, Austin Afani, Seun Odedeji, Taiwo Ogundalu, Seyi Ajala (Criminology), Mr. Dapo Olakunlehin, Adewumi Michael, and also Kayode Adesuyi and others. May we continue to grow greater and mightier in knowledge, understanding and wisdom in Jesus mighty name.

\section{Conflicts of interest}

The author declares there are no conflicts of interest.

\section{Funding}

None.

\section{References}

1. Nwanegbo CJ, Odigbo J. Security and national development in Nigeria:
The threat of Boko Haram. International Journal of Humanities and Social Science. 2013;3(4):1-7.

2. Iwarimie Jaja D. Criminology: The criminology's eye in reoccurring crime problems in nigeria. 2013.

3. Tolu M, Lawal M, Abe O. National development in Nigeria: Issues, challenges and prospects. Journal of Public Administration and Policy Research. 2011;3(9):237-241.

4. Kaplan H, Sadock B. Psychoactive substance use disorders. In: Synopsis of Psychiatry. 8th edn. 1997.

5. Adegboro E. Drug abuse among students of Adekunle Ajasin University, Akungba Akoko, Ondo State, Nigeria. International Journal of Education and Research. 2014;2(4):1-8.

6. Makanjuola BA, Oyeleke SA, Akande TM. Psychoactive substance use among long distance vehicle drivers in Ilorin. Nigerian Journal of Psychiatry. 2007;5:14-18.

7. Abiona TC, Aloba OO, Fatoye FO. Pattern of alcohol consumption among commercial road transport workers in a semi-urban community in South Western Nigeria. East African Medical Journal. 2006;83(9):494499.

8. Oyebode W. Crime fact Online Magazine. 2015

9. Wendy L, Toumbourou JW, Stockwell T, et al. The Prevention of Substance Use, Risk and Harm in Australia: a review of the evidence. Monograph of the National Drug Research Centre and the Centre for Adolescent Health, Australia. 2004.

10. Lander L, Howsare J, Byrne M. The impact of substance use disorders on families and children: From theory to practice. Soc Work Public Health. 2013;28(3-4):194-205.

11. Adekoya BJ, Adekoya AO, Adepoju FG, et al. Driving under influence among long distance commercial drivers in Ilorin, Nigeria. International Journal of Biological \& Medical Research. 2011;2(4):870-873.

12. Aaarts L, Van Schagen L. Driving speed and the risk of road crashes: A review. Accident Anal. Prev. 2006;38(2):215-224.

13. Wood DS. A review of research on alcohol and drug use, criminal behaviour, and the criminal justice system response in America Indian and Alaska Native Community. 2009.

14. Oluwadiya SK, Faraoye FO. Taking alcohol by deception II: Paraga (alcoholic herbal mixture) use among commercial motor drivers in a South-Western Nigeria City. BMC Research Note. 2012;5:301

15. Okuh B. Problems of secondary school learners. Careers. 1978;2(3)

16. Oduaran D. Psychological guidance of the school child. Ibadan, Evans Books. 1978

17. Johnson MP. Power relaxations and affective style as determinants on confidence in impression formation in a game situation. Journal of Experimental Social Psychology. 1979;7:98-100.

18. Fareo DO. Drug abuse among Nigerian adolescents strategies for counseling. The Journal of International Social Research. 2012;5(20):1-

19. National Drug Law Enforcement Agency (NDLEA). Drug data collection and research, Lagos: Drug Demand Reduction Unit, National Drug Law Enforcement Agency. In: Fareo DO. editor. Drug abuse among Nigeria adolescents strategies for counselling. The Journal of International Social Research. 2012;5(20):341-347.

20. World Book Encyclopedia. Vol. 6, Chicago: World Book. 2004.

21. Manbe DA. Crime and drug abuse among Nigerian youths: A critical examination in World Health Organization(WHO). Expert Committee on Drug Dependence. 2008. 
22. Ajayi IA, Ayodele JB. History and development of education in AdoEkiti, Nigeria. Nigeria: Petoa Education Publishers. 2002

23. Egbochuku EO, Akerele JO. Stimulant use as correlate of abusive behaviour among Nigerian undergraduates: College Student Journal. 2007;4(1):50-58.

24. Ajayi IA, Ekundayo HT. Contemporary issues in educational management, Lagos, Nigeria: Bolabay Publications. 2010.

25. Laver RH. Social problems and the quality of life. Lowa: C. Brown Publishing Company. 1978.

26. World Health Organisation. Programme on substance abuse, 'Preventing Substance Abuse in Families: A WHO Position Paper'. Geneva. 1996.

27. World Health Organisation. The global burden of psychoactive substance use. World Health Organization. Geneva: Switzerland. 2002.

28. Egbe M. The effect of drug abuse among university undergraduates in Nigeria: A study of the university of Calabar. 2013.

29. Oxford English Dictionary. New York: Oxford University Press. 2010.

30. Oxford Dictionary of Sociology. New York: Oxford University Press. 2005 .

31. Marshall RJ. A psychoanalytic perspective on the diagnosis and development of juvenile delinquency. In: WS Laufer, JM Day, editors. Personality theory, moral development and criminal behaviour. 1983.

32. Pela DA, Ebile JC. Some aspects of drug use among students in Benin City Nigeria. Drug Alcohol Depend. 1981;8(4):265-270.

33. Ajila OA. A Study of some causative factors of substance abuse among secondary school students in Ibadan. An Unpublished M.Ed. Dissertation, University of Ibadan, Ibadan. 2001.

34. Okpataku CI. Substance use among long distance commercial vehicle drivers: Onset and the influence of education. MJP Online Early. Original Paper. 2015.

35. Bandura A, Walters RH. Social learning and personality development. New York: Holt, Rinehart, and Winston. 1963.

36. Bandura A. Social learning theory. Eaglewood Cliffs, Prentice Hall. In: Jiloha RC. Editor. Social and cultural aspects of drug abuse in adolescents. Delhi Psychiatry Journal. 2009;12(2)1-9.

37. Bandura A. Social learning theory. Oxford, England: Prentice-Hall. In: David S, Derald A, et al. editors. Understanding abnormal behaviour 3rd edn. 1990.
38. Gilly K, Adi L, Eldad Y. A model of the initial stages of drug abuse: From reinforcement learning to social contagion. Journal of Study on Alcohol and Drugs. 2014;70:776-785.

39. Lamiel JT. The psychology of personality. New York: Columbia University Press. 1987.

40. Freud S. A difficulty in the path of psychoanalysis. 1917.

41. Curran DJ, Renzetti CM. Theories of crime. Boston, USA: Allyn and Bacon. 1994;100:102-103.

42. Eze JE, Omeje. Fundamentals of substance abuse. Enugu: Snaap Press Ltd. 1999.

43. David S, Derald A, Stanley S. Understanding abnormal behaviour 3rd edn. Houghton Miffin Company Boston, Dallas Geneva, Illinois Palo Alto Princeton, New Jersey. 1990.

44. Hawkins JD, Catalano RF, Miller JY. Risk and protective factors for alcohol and other drug problems in adolescence and early adulthood: Implications for substance abuse prevention. Psychological Bulletin. 1992;112(1):64-105.

45. Kleinmuntz B. Personality and psychological assessment. New York: St Martin's Press. 1982.

46. Warren MQ. The female offender. In: H Toch, editor. Psychology of crime and criminal justice. 1976.

47. Matsueda RL. The current state of differential association theory. Crime and Delinquency. 1988;34(3):277-306.

48. National Association of Conservation Districts (NACD). Annual Report. 2013.

49. Nigeria Stability \& Reconciliation Programme. Policy brief: How an improved understanding of drug use can contribute to peace and stability in Nigeria. International Alert. 2017

50. Reckless WC. The etiology relation between personal traits and associational patterns. Social Science Research Bulletin. 1943;50:131137.

51. Rodney W. How Europe underdeveloped Africa. London: Bogle L'Overture Publication. 1972.

52. Tramadol withdrawal and detox, addiction center. 